\title{
PROF. DR. B. J. ENGELBRECHT, HOOGLERAAR VIR 25 JAAR
}

Prof. dr. Barend Jacobus Engelbrecht is op 1 Augustus 1923 gebore en het op 1 Februarie 1952 diens as professor in Dogmatiek en Christelike Etiek aan die Universiteit van Pretoria aanvaar.

Onder sy leiding is vier doktorale proefskrifte in die Dogmatiek, twee in die Praktiese Teologie en een in die Nuwe Testamentiese Wetenskap voltooi. Van sy kollegas in die fakulteit het twee onder sy promotorskap gedoktoreer en nog twee Dogmatiek as byvak vir die doktorale eksamen bestudeer. Vanaf 1952 tot 1976 het byna 200 predikante van die Nederduitsch Hervormde Kerk by hom vir die B.D.-Studie lesings gevolg. Oor 'n tydperk van 25 jaar het prof. Engelbrecht bowendien deur talle publikasies en adviese 'n groot bydrae tot die vorming van die teologiese denke in Suid-Afrika gelewer.

Vir die redaksie van die Hervormde Teologiese Studies is dit 'n voorreg en 'n eer om by wyse van hierdie uitgawe aan prof. Engelbrecht 'n woord van dank oor te dra en hom as leier in kerk, akademie en kultuur te huldig. Dit is ons bede dat hy van krag tot krag sal gaan en vir kerk en teologie nog baie vrugbare jare geskenk sal word.

Ons dank aan prof. dr. J. A. Heyns en aan die kollegas en oud-studente van prof. Engelbrecht vir die ontvange bydraes.

Namens die Redaksie,

J. P. Oberhoker 